\title{
Correction to: Potato virus X-mediated constitutive expression of Plutella xylostella PXSDF2L 1 gene in Nicotiana benthamiana confers resistance to Phytophthora parasitica var. nicotianae
}

Ivis Moran-Bertot ${ }^{1 \dagger}$, Lianet Rodríguez-Cabrera ${ }^{1 \dagger}$, Orlando Borras-Hidalgo ${ }^{1,2}$, Siliang Huang ${ }^{3}$, Yunchao Kan $^{3}$, Denis J. Wright ${ }^{4^{*}}$ and Camilo Ayra-Pardo ${ }^{3 *}$ (1)

Correction to: BMC Plant Biol 21, 78 (2021)

https://doi.org/10.1186/s12870-021-02854-5

Following publication of the original article [1], an error was found in the Acknowledgement section. "Camilo Ayra-Pardo was a grantee of the Henan Science and Technology Department (Project no. HNGD2021049) in China." Has to be added in the Acknowledgement section of the article.

The original article has been corrected.

\footnotetext{
Author details

'Plant Division, Centre for Genetic Engineering and Biotechnology (CIGB), 10600 Havana, Cuba. ${ }^{2}$ Shandong Provincial Key Laboratory of Microbial Engineering, School of Biotechnology, Qi Lu University of Technology, Jinan 250353, Shandong, People's Republic of China. ${ }^{3}$ China-UK-NYNU-RRES Joint Laboratory of Insect Biology, Nanyang Normal University (NYNU),
}

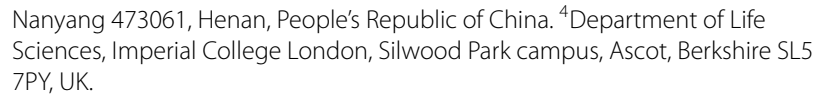

Nanyang 473061, Henan, People's Republic of China. ${ }^{4}$ Department of Life Sciences, Imperial College London, Silwood Park campus, Ascot, Berkshire SL5 7PY, UK.

Published online: 23 November 2021

\section{Reference}

1. Moran-Bertot I, Rodríguez-Cabrera L, Borras-Hidalgo O, et al. Potato virus X-mediated constitutive expression of Plutella xylostella PXSDF2L1 gene in Nicotiana benthamiana confers resistance to Phytophthora parasitica var. nicotianae. BMC Plant Biol. 2021;21:78. https://doi.org/10.1186/ s12870-021-02854-5.

The original article can be found online at https://doi.org/10.1186/s12870021-02854-5.

\footnotetext{
*Correspondence: d.wright@imperial.ac.uk; cayrapardo73@yahoo.com ${ }^{+}$Ivis Moran-Bertot and Lianet Rodríguez-Cabrera contributed equally to this work.

${ }^{3}$ China-UK-NYNU-RRES Joint Laboratory of Insect Biology, Nanyang Normal University (NYNU), Nanyang 473061, Henan, People's Republic of China

${ }^{4}$ Department of Life Sciences, Imperial College London, Silwood Park campus, Ascot, Berkshire SL5 7PY, UK

Full list of author information is available at the end of the article
}

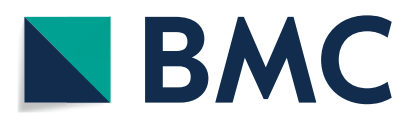

(c) The Author(s) 2021. Open Access This article is licensed under a Creative Commons Attribution 4.0 International License, which permits use, sharing, adaptation, distribution and reproduction in any medium or format, as long as you give appropriate credit to the original author(s) and the source, provide a link to the Creative Commons licence, and indicate if changes were made. The images or other third party material in this article are included in the article's Creative Commons licence, unless indicated otherwise in a credit line to the material. If material is not included in the article's Creative Commons licence and your intended use is not permitted by statutory regulation or exceeds the permitted use, you will need to obtain permission directly from the copyright holder. To view a copy of this licence, visit http://creativecommons.org/licenses/by/4.0/. The Creative Commons Public Domain Dedication waiver (http://creativeco mmons.org/publicdomain/zero/1.0/) applies to the data made available in this article, unless otherwise stated in a credit line to the data. 